Pre-print copy of paper published: Agbenyega O, Burgess PJ, Cook, M, Morris J (2009). Application of an ecosystem function framework to perceptions of community woodlands. Land Use Policy 26: 551-557.

\title{
Application of an ecosystem function framework to perceptions of community woodlands
}

\author{
Olivia Agbenyega, Paul J. Burgess*, Matthew Cook, Joe Morris \\ School of Applied Sciences, Cranfield University, Cranfield, Bedfordshire, MK43 0AL, UK
}

\begin{abstract}
Owners, local residents, government, and conservation organisations can express divergent preferences in the development and management of local woodlands. The perceptions of these four groups were examined, in the context of three community woodlands in Eastern England, using an ecosystem function framework. In a pilot study, residents were able to allocate a relative importance to woodland ecosystem services which were then related to "regulation", "habitat", and "production" or "information" functions. However residents also placed importance on negative services or "disservices" associated with the woodland ecosystem. Therefore a fifth category of "disservices" was included in the main survey which included 84 local residents, three woodland owners, three government institutions, and six representatives from conservation groups. Each of the four groups placed greatest importance on services associated with habitat (16-39\% of the total importance) and information (30-50\%) functions suggesting, in this example, mutual interest in the use of woodlands as a habitat or recreational resource. By contrast a potential area of difference was the particularly high importance placed by one owner on dis-services such as fly-tipping. In addition the woodland owners placed higher importance (10-20\%), than local residents and conservation groups (7-9\%), on the productive services of the wood. This suggests a need for communication when production-related operations affect recreation. The ecosystem function framework appears to be a useful approach for highlighting potential tensions and areas of mutual interest in the management of semi-natural ecosystems.
\end{abstract}

Keywords: Ecosystem, functions, goods, service, community, woodlands, stakeholder, recreation, owner, forest.

*Corresponding author: P.Burgess@cranfield.ac.uk 


\section{Introduction}

In the UK, woodlands have been defined as land with trees where the mature trees would cover more than $20 \%$ by area (Forestry Commission, 2004). Woodland types range from large areas, generally called forests, to smaller areas known by terms such as woods, copses and shelterbelts. Since 1988 the government in the UK, as in other countries in the European Union, has provided grant schemes to support landowners who plant new woodlands. The aims of such schemes have included reducing agricultural surpluses, enhancing the landscape, creating new wildlife habitats, encouraging recreational use, supporting farm income and rural employment, and supplying timber (Rollinson, 1999). Between 1996 and 1998, one particular grant was the "Community Woodland Supplement" which supported the planting of new community woodlands within $8 \mathrm{~km}$ of a village, town, or city, where there are few other types of woodland available for recreation (Forestry Commission, 1998). The typical additional grant available for such woodlands was $£ 950$ per hectare (1996-1998 prices). Hence in the context of this paper, community woodlands are defined as areas of trees with free public access close to a significant population centre.

This paper has three main objectives: (i) to determine the applicability of an ecosystem functions approach to classifying the diverse array of functions and services generated by semi-natural ecosystems such as community woodlands, (ii) to link these multiple functions and services with particular stakeholder interests and preferences, and (iii) to explore potential synergies and tensions. Following a brief review of the principles of ecosystem and stakeholder analyses, the paper explains the methods used to meet the research objectives, and presents the results of a pilot and main stakeholder survey. The results are discussed in terms of the applicability of the framework, the responses of individual stakeholders, and a consideration of how the framework can be used to identify and address potential areas of synergy and tension.

\section{Ecosystems framework}

The ecosystems framework adopts an anthropogenic viewpoint in that it links the stock of natural assets found in land, water, air and living systems, with an associated flow of services that provide benefits to people and communities. The assets are often termed "natural capital", which are associated with a range of processes or "functions", which can provide goods and services (items that confer benefit and advantage) to meet human needs, directly or indirectly (Turner et al., 2000; de Groot et al., 2002, Farber et al., 2002; Hein et al., 2006; de Groot, 2006; Zhang et al., 2007). Such an approach reinforces Daily's (1997) description of the public benefits of ecosystem uses, goods and services that sustain and fulfil human life. These concepts have been used by the Millennium Ecosystem Assessment (2005) to represent the flow of benefits to society generated by stocks of renewable natural resources and related ecosystems, and the consequences for human well-being.

De Groot et al. (2002) use the term "ecosystem function" to describe "the capacity of natural processes and components to provide goods and services that satisfy human needs". They then list four categories of functions in the order of 'regulation', 'habitat', 
'production', and 'information', with the functioning of the last two categories being dependent on the first two.

- Regulation functions - the capacity to regulate essential ecological processes and life support systems i.e. regulating climatic, water, soil, nutrients, ecological and genetic conditions.

- Habitat functions - provision of a place for plants and animals, helping with the conservation of genetic, species and ecosystem diversity (the habitat function is sometimes referred to as a carrier function).

- Production functions - the capacity to create biomass and thereby the production of goods such as food, raw materials, and energy resources.

- Information functions - the capacity to contribute to human well-being through knowledge and experience and sense of relationship with context e.g. spiritual experiences, aesthetic pleasure, cognition and recreation.

Within each of these functions it is also possible to identify specific "uses" which are the goods and services obtained from a particular function category (de Groot et al., 2002).

\section{Stakeholder interests and preferences}

The anthropocentric focus of the ecosystem function approach requires an appreciation of the distribution of the flows of actual or potential goods and services amongst different stakeholder groups (Turner et al., 2000). Stakeholders are individuals, groups or organisations with an interest in a particular phenomenon, further distinguished according to the degree to which they can influence the phenomenon of concern (Friedman and Miles, 2006). In this context, it can be useful to understand the importance of entitlement and property rights in terms of the claims placed on the services described by the ecosystem approach (Bromley, 1991; Baltzer, 1998). Selman (1996) argues that in the UK the location and design of new woodlands and the management of existing woodlands has largely been determined by woodland owners, who often have an interest in a particular service, e.g. timber production or conservation, with a high degree of influence through their ownership of the land. However as discussed earlier, the UK government and the European Union have invested public money in the form of grants in the establishment of new woodlands. Hence it is arguable that the public good aspects of community woodlands need to become better defined so that stakeholder interests, preferences and values are adequately accounted for in future management decisions. This balancing of the requirements of key stakeholders whilst, where possible, maintaining the integrity of the ecosystem is a difficult task that requires a sound understanding of existing social, economic and environmental interactions (Ravnborg \& Westermann 2002; O’Brien, 2004). In some cases this may require a wider knowledge by key stakeholders of the importance of ecosystem functions (Lewan \& Söderqvist, 2002), and in turn greater information and stakeholder engagement may also increase the demand for the ecosystem services of community woodlands. 


\section{Materials and methods}

The method was based on a case study strategy involving three community woodlands. The sites, all in Bedfordshire in Eastern England, were selected because they had contrasting forms of woodland ownership, each was open to the public, and each had received governmental support to encourage public access. The woodlands comprised one of mainly poplar (Populus spp.) species (Pegnut Wood, 52 ${ }^{\circ} 7^{\prime} \mathrm{N} ; 0^{\circ} 13^{\prime} \mathrm{W} ; 35 \mathrm{~m}$ above sea level); and two of mixed-broadleaf species (Clapham Park Wood, 52 $10^{\prime} \mathrm{N}$; $0^{\circ} 28^{\prime} \mathrm{W}$; $60 \mathrm{~m}$ and Reynolds Wood, 52²' N; 0³6' W; $75 \mathrm{~m}$ ). Pegnut Wood, at the edge of the town of Potton, comprises 36.5 ha of poplar planted between 1994 and 1996 on land owned by an agri-business co-operative. Clapham Park Wood comprises 21 ha of mixed broadleaf woodland and silvopastoral agroforestry mainly oak (Quercus robur) and ash (Fraxinus excelsior) situated in the parish of Brickhill, north-west of the county town of Bedford. This woodland belongs to a local government authority. It was established as a demonstration wood in 1998 (Burgess et al., 2000). Reynolds Wood, near Brogborough is a 100 ha mixed broadleaf woodland, planted in 1993 belonging to a charitable trust and managed with support from the local government authority.

The next step in the method had two objectives: i) the compilation of a list of ecosystem services provided by community woodlands, and ii) the assessment of the suitability of a questionnaire to determine the importance that local residents placed on those services. An initial literature review provided an initial list of a range of regulating, habitat, production and information services (Costanza et al. 1997; de Groot et al. 2002; Turner et al. 2003). The appropriateness of the list and the suitability of a questionnaire were then evaluated in pilot interviews with 20 respondents living close to Pegnut Wood in January and February 2005. The questionnaire was constructed so that it contained four initial sections, matching the four categories of ecosystem function. In each section, the respondents were asked to allocate 100 points indicating the relative importance to them of the services derived from each category of function, thereby creating an ordinal numerical measure of the importance that individuals indicated for each service (Neuman, 2003) (Table 1). In addition to the identified services, "other services” was also always included as an option. Once this was completed, the respondents were asked to allocate a further 100 points to indicate the relative importance of the four categories: regulation, habitat, production and information. In the pilot survey, a number of respondents raised issues including the presence of fly-tipping, litter, and dog excrement. Whilst early use of the ecosystem approach has tended to concentrate on the positive services of ecosystems, Zhang et al. (2007) have highlighted the role of dis-services in agricultural ecosystems. Such dis-services are environmental 'bads' borne by one party without compensation as result of actions (or inaction) by another party. To respond to this, after the pilot survey a fifth category of "negative" or dis-services was included (Table 1). Although in the survey dis-services were included as a separate group, it is also possible to consider them as "negative" aspects of regulating, habitat, production, or information services. In fact, the perception of whether the service is positive or negative will depend on the user, e.g. the tendency of woodland to attract fly-tipping waste may be seen as negative by a walker, but a benefit by the person disposing of the waste. 
Table 1: Ecosystem functions and related services and dis-services of community woodlands as used in the main survey. The list of services was based on Costanza et al. (1997), de Groot et al. (2002), Turner et al. (2003) and feedback from the pilot survey.

\begin{tabular}{|c|c|c|}
\hline $\begin{array}{l}\text { Ecosystem } \\
\text { functions }\end{array}$ & Services & Dis-services \\
\hline \multirow[t]{8}{*}{ Regulation } & Carbon storage & \\
\hline & Favourable microclimate & \\
\hline & Soil protection & \\
\hline & Wind protection & \\
\hline & Dust removal & \\
\hline & Noise reduction & \\
\hline & Flood prevention & \\
\hline & Derelict site restoration & \\
\hline \multirow[t]{4}{*}{ Habitat } & Habitat for wild plant/animal species & \\
\hline & Plant conservation & \\
\hline & Deer and game bird conservation & \\
\hline & Other animal conservation & \\
\hline \multirow[t]{4}{*}{ Production } & Timber production & \\
\hline & Fuelwood/charcoal production & \\
\hline & Nut and fruit production & \\
\hline & Employment & \\
\hline \multirow[t]{7}{*}{ Information } & Walking $^{1}$ & Fly tipping \\
\hline & Dog walking & Dog excrement and litter disposal \\
\hline & Game shooting & Drug use \\
\hline & Landscape appreciation & Other criminal activity \\
\hline & Education and research & \\
\hline & Urban growth control & \\
\hline & Landscape screening & \\
\hline
\end{tabular}

Note: ${ }^{1}$. Walking was not included in the survey of residents.

After the pilot survey, a full survey of local residents took place between February and September 2005. Data were collected via semi-structured interviews and structured selfadministered questionnaires with 200 individuals living in residential areas adjacent to the selected woodlands namely Potton (80), Brickhill (80) and Brogborough (40). The individuals were selected randomly from the sampling frame of local electoral registers and each respondent was given the questionnaire in person. Between February and April 2006, a similar questionnaire was posted to the three woodland owners, three representatives of governmental institutions, and six representatives from conservation groups, following initial discussions in person or by electronic mail and telephone. Unfortunately although "walking” and "dog-walking” were included separately in the second set of questionnaires, "walking" was omitted in the questionnaires given to residents. The governmental institutions were forestry and woodland related. The representatives of the conservation groups were locally-based and associated with the British Trust for Conservation Volunteers.

Completed survey forms were received from 39 residents of Potton (49\% response rate), 38 people at Brickhill (47\% response rate) and 7 residents of Brogborough (18\% response rate). The results from the survey were checked, entered onto a computer and statistically analysed using a non-parametric Friedman analysis of variance within the Statistica Software package. The results were then analysed for similarities and 
differences to identify potential synergies and tensions between stakeholders relating to the ecosystem function, use and value of community woods.

\section{Results}

The results are described in terms of the relative weighting of importance given to the five categories of ecosystem services, and then in terms of the specific services within each category.

\section{Stakeholder perceptions of ecosystem functions}

Local residents placed different $(p<0.001)$ levels of importance on the five categories of ecosystem services (Figure 1a). A greater importance was placed on the positive services associated with the information (37\% of the total importance) and habitat (33\%) functions, than the regulation (17\%) and production (7\%) functions. Local residents also ascribed a substantial level of importance (6\%) to negative services

Each woodland owner also ascribed a greater importance to the positive services provided by the information (30-40\%) and habitat functions (20-40\%) than the production and regulation functions (10-20\%) (Figure 1b). However two of the three owners also placed a high level of importance (10-20\%) on negative services. Overall, the three representatives of the government institutions ascribed a higher level of relative importance (50\%) to positive information services, and a lower level of relative importance to positive habitat services than other stakeholders. As may be expected, the woodland conservation groups placed the greatest relative importance on the positive habitat services (39\%) of the woodland.

\section{Regulation services}

The four groups of stakeholders allocated between 10 and 18\% of the overall importance of community woodlands to regulation services (Figure 1). When local residents were asked to identify the relative importance of individual regulating services, the greatest weighting $(p<0.001)$, out of a total of about $16 \%$, was allocated to regulating a favourable microclimate (3\%), followed by soil protection, site restoration, carbon storage, noise reduction, and wind protection (all 2\%) (Table 2). When the woodland owners were asked to indicate the importance of regulation services, carbon storage (2$3 \%)$; flood prevention (1-3\%) and creation of a favourable climate (1-2\%) were ranked most highly (Table 2). The representatives of the government institutions also allocated the greatest $(p=0.06)$ relative importance, out of a total of $13 \%$, to carbon storage, flood prevention, and links to other schemes ( $3 \%$ each). There was no significant $(p=0.33)$ differences in the weighting given by the conservation groups to different regulation services.

\section{Habitat services}

Local residents, who ascribed 33\% of the total importance of the woodlands to habitat services (Figure 1), ascribed a greater value $(p<0.001)$ to the provision of wild animal and wild plant habitats (14\%), than for plant conservation, deer and game bird conservation, and other animal conservation (all 6-7\%) (Table 2). The conservation groups, who ascribed 39\% of the total importance to habitat services (Figure 1a), also placed greater $(p<0.001)$ importance on the provision wild plants and animal habitats (25\%) than deer and game bird conservation (1\%) (Table 2). By contrast the government representatives and two of the three owners placed a similar importance on 
the conservation of plants and animals as the provision of a habitat for wild plants and animals (Table 2).

\section{a) Local residents, government institutions, and conservation groups}

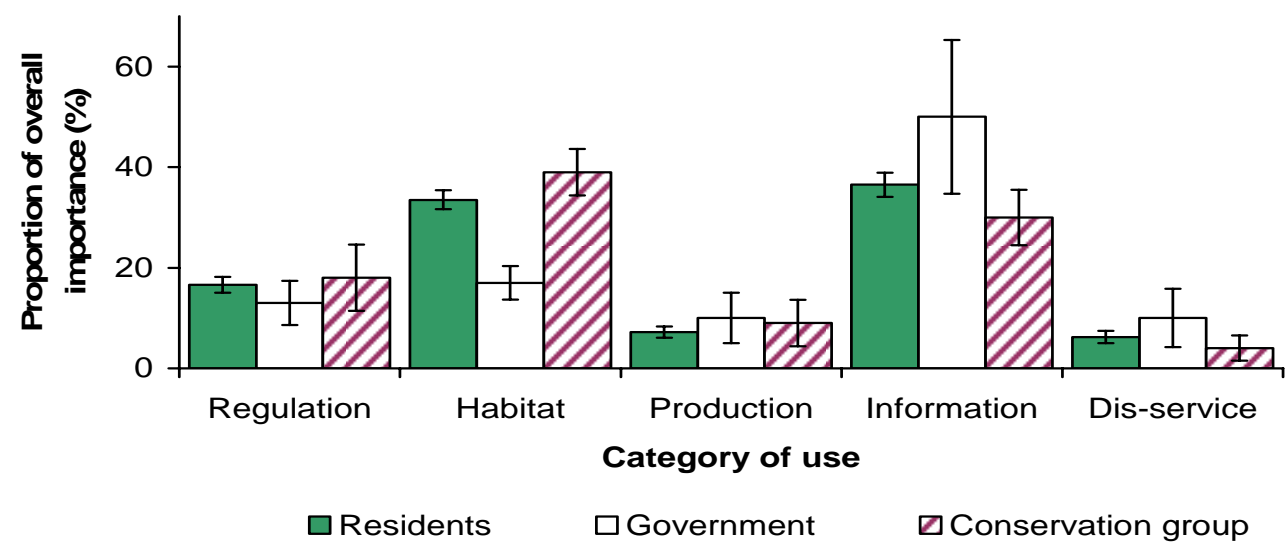

b) Owners

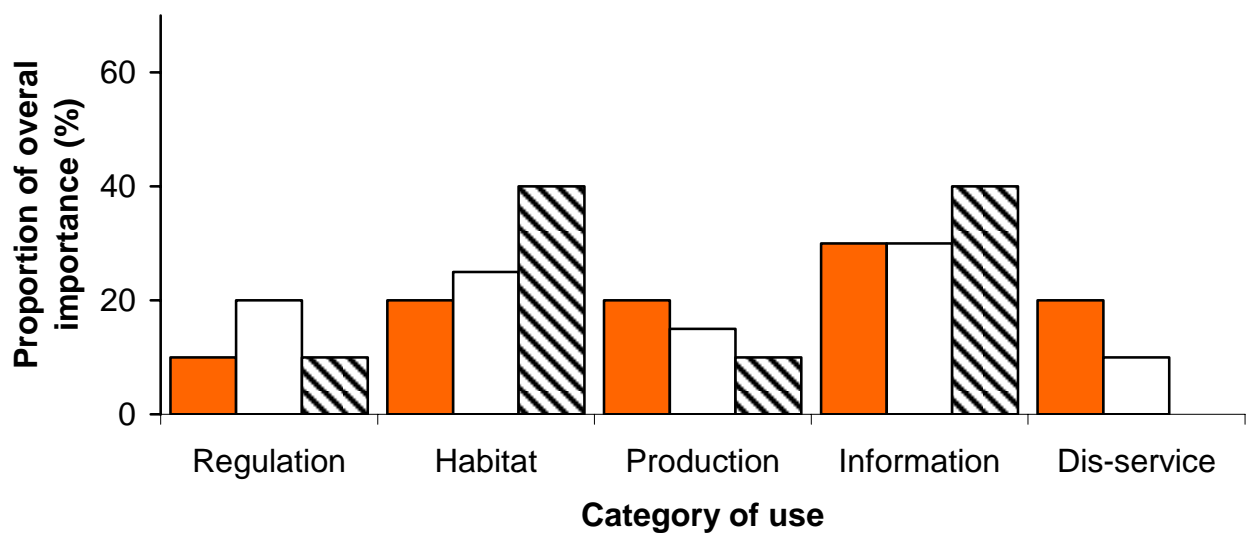

$\square$ Agribusiness co-operative $\quad \square$ Local authority $\quad \mathbf{\nabla}$ Charitable trust

Figure 1. Relative valuation of five categories of community woodland use by a) local residents ( $\mathrm{n}=84)$, government institutions $(n=3)$ and local conservation groups $(n=6)$, and $b)$ each of three woodland owners $(\mathrm{n}=1)$. The dis-service category primarily relates to information dis-services. Error bars show standard errors.

\section{Production services}

Amongst the stakeholders interviewed, the agribusiness co-operative placed the greatest importance on the production services of the woodland (20\%), and specifically the use of the woodland for timber production (14\%) and employment (6\%). Of the other stakeholders, no stakeholder placed more than $5 \%$ on the importance of a specific production service. In fact local residents, who ascribed a relative importance of only $7 \%$ to production services, ascribed similar $(p=0.26)$ values $(1$ to $2 \%)$ to the use of the woodland for providing timber, fuelwood, nuts and fruits and employment. Similar results were obtained from the local government authority and charitable trust woodland owner, and the representatives of government institutions and conservation groups (Table 2). 
Table 2: Relative importance (\%) of each of 30 ecosystem services/dis-services of community woodlands as perceived by 84 local residents, three woodland owners (agribusiness co-operative, local authority, trust), three representatives of government institutions, and six representatives of conservation groups. Numbers above $5 \%$ are indicated in bold.

\begin{tabular}{|c|c|c|c|c|c|c|}
\hline \multirow[t]{2}{*}{ Services } & \multirow{2}{*}{$\begin{array}{l}\text { Residents } \\
(\mathrm{n}=84)\end{array}$} & \multicolumn{3}{|c|}{ Owners } & \multirow{2}{*}{$\begin{array}{l}\text { Government } \\
\text { representatives } \\
(\mathrm{n}=3)\end{array}$} & \multirow{2}{*}{$\begin{array}{l}\text { Conservation } \\
\text { groups } \\
(\mathrm{n}=6)\end{array}$} \\
\hline & & $\begin{array}{l}\text { Agri- } \\
\text { business } \\
(n=1)\end{array}$ & $\begin{array}{l}\text { Local } \\
\text { authority } \\
(\mathrm{n}=1)\end{array}$ & $\begin{array}{l}\text { Trust } \\
(n=1)\end{array}$ & & \\
\hline \multicolumn{7}{|l|}{ Regulation service } \\
\hline Carbon storage & 2 & 2 & 3 & 2 & 3 & 3 \\
\hline Favourable climate & 3 & 2 & 2 & 1 & 1 & 2 \\
\hline Soil protection & 2 & 1 & 2 & 1 & 1 & 2 \\
\hline Wind protection & 2 & 1 & 2 & 1 & 0 & 2 \\
\hline Dust removal & 1 & 1 & 2 & 1 & 0 & 2 \\
\hline Noise reduction & 2 & 1 & 2 & 1 & 0 & 4 \\
\hline Flood prevention & 2 & 1 & 3 & 1 & 2 & 1 \\
\hline Site restoration & 2 & 1 & 2 & 1 & 3 & 2 \\
\hline Links to other schemes & 0 & 0 & 0 & 1 & 3 & 0 \\
\hline \multicolumn{7}{|l|}{ Habitat service } \\
\hline Wild plant/animal & 14 & 5 & 8 & 32 & 4 & 25 \\
\hline Plant conservation & 7 & 5 & 8 & 2 & 5 & 9 \\
\hline Deer and game conservation & 6 & 5 & 0 & 0 & 3 & 1 \\
\hline Other animal conservation & 6 & 5 & 5 & 2 & 3 & 4 \\
\hline Species management & 0 & 0 & 5 & 4 & 1 & 0 \\
\hline \multicolumn{7}{|l|}{ Provisioning service } \\
\hline Timber production & 2 & 14 & 3 & 1 & 5 & 3 \\
\hline Fuelwood production & 1 & 0 & 5 & 1 & 2 & 2 \\
\hline Nut and fruit production & 2 & 0 & 5 & 5 & 1 & 2 \\
\hline Employment $^{\mathrm{a}}$ & 2 & 6 & 3 & 3 & 3 & 2 \\
\hline \multicolumn{7}{|l|}{ Information service } \\
\hline Walking & $6^{\mathbf{b}}$ & 9 & 12 & 28 & 17 & 15 \\
\hline Game shooting & 1 & 0 & 0 & 0 & 2 & 0 \\
\hline Cultural appreciation & 6 & 6 & 3 & 2 & 9 & 5 \\
\hline Landscape appreciation & 12 & 6 & 6 & 2 & 10 & 6 \\
\hline Education and research & 5 & 6 & 5 & 2 & 7 & 1 \\
\hline Horse riding & 1 & 0 & 0 & 2 & 0 & 0 \\
\hline Urban growth control & 4 & 3 & 2 & 4 & 3 & 1 \\
\hline Landscape screening & 3 & 0 & 2 & 0 & 1 & 2 \\
\hline \multicolumn{7}{|l|}{ Dis-service } \\
\hline Fly tipping & 3 & 8 & 3 & 0 & 3 & 2 \\
\hline Dog excrement and litter & 1 & 6 & 5 & 0 & 5 & 1 \\
\hline Drug use & 1 & 3 & 1 & 0 & 1 & 0 \\
\hline Other criminal activity & 1 & 3 & 1 & 0 & 2 & 1 \\
\hline Total & 100 & 100 & 100 & 100 & 100 & 100 \\
\hline
\end{tabular}

a: Employment was assumed to be primarily related to timber production.

${ }^{b}$ : Residents were only given the option of “dog-walking” rather than both "walking” and "dog-walking” 


\section{Information services}

Local residents ascribed $37 \%$ of the importance of the community woods to positive information services (Figure 1). Although the results were not statistically significant ( $p$ $=0.32$ ), local residents indicated that the most important beneficial information services provided by the woodland were a scenic and beautiful landscape (12\%), an opportunity for dog-walking (6\%), and cultural appreciation (6\%) (Table 2). Unfortunately "walking”, as distinct from "dog-walking" was omitted in the questionnaire used with residents. When it was included, government institutions and the conservation groups (15-17\%) and the charitable trust (28\%) allocated a high importance to the use of the woodland for walks (with and without dogs). Beyond walking, stakeholders other than local residents, also ranked the provision of a scenic landscape (2-10\%) and cultural value (2-9\%) as the most important information services provided by the woodland. The relative importance placed on game shooting (0-2\%), horse riding (0-2\%), landscape screening (0-3\%), and the control of urban growth (1-4\%) was relatively low.

\section{Information dis-services}

Local residents ascribed a relatively low level of importance (6\%) to the negative services or dis-services created by community woodlands (Figure 1a). Within this total, the importance placed on flying tipping $(3 \%)$ was greater $(p<0.001)$ than that attributed to dog excrement and litter, drug use and criminal activities (all 1\%) (Table 2). The conservation groups also ascribed some importance (4\%) to negative services (Figure 1a), with the greatest importance again placed on fly tipping (Table 2). By contrast two of the woodland owners, the agribusiness co-operative and the local authority, placed a substantially higher importance (10-20\%) on a range of negative services including flytipping (3-8\%) and dog excrement and litter (5-6\%). The three representatives of government institutions also placed a similar importance (3-5\%) on fly tipping and dog excrement as problems (Table 2); by contrast in this study the charitable trust placed no importance on these dis-services.

\section{Discussion}

This section first discusses the general applicability of the ecosystem function framework to community woodlands. It then discusses the responses of the individual stakeholders and lastly considers how the framework can be used to identify and address potential areas of synergy or tension.

Applicability of the ecosystem functions framework

The research showed that when participants were provided with a list of potential ecosystem services, they could use the framework to describe the perceived importance of those ecosystem services and the associated functions. The framework was particularly useful in providing an overarching systematic structure to the wide range of existing and potential services. Such an analysis could be particularly instructive when an owner considers the purpose in planting new woodland. This is because it allows different functions and services to be examined relative to each other, without the need to monetise terms, and it highlights functions and services that may otherwise have been ignored. Whilst community woodlands provide some services that can be allocated to an individual e.g. timber production, they also produce a range of goods and services which are collectively consumed (Wilson \& Howarth 2002) and the framework provides a mechanism for recognising these additional contributions to society as a whole. 
Local residents

Local residents perceived that the greatest value of community woodlands was in terms of the habitat and information services provided. This is similar to Chambers and Price (1986), Arnberger (2006) and Ode and Fry (2006) who report that local residents placed primary importance on the recreational use of woodlands. De Groot et al. (2002) explain that ecosystem functions can have economic, social and ecological values. The focus of the residents on habitat and information services implies that they primarily focussed on ecological (habitat) and social (information) values. By contrast, the results suggest that the current value placed on regulating services is relatively low. This is in contrast to research on wetlands in Sweden which showed that local stakeholders tended to rank the value of regulating services higher than those related to recreation (Lewan and Söderqvuist, 2002). It is possible that because regulating services are "invisible" they are under-valued, and that an "accurate" assessment may depend on improved understanding (Hoehn et al., 2003; Lewan and Söderqvuist, 2002).

\section{Woodland owners}

The agribusiness co-operative and the local government authority gave greatest importance to information services, whilst the charitable trust placed greatest importance on services related to habitat functions. The charitable trust's response is in line with their stated objective of enabling the survival and evolution of the widest range of habitats and species and enhancing biodiversity. Within the information function, the greatest value was placed on the use of woods for walking. In a study of woodland owners' attitudes to public access provision, Church et al. (2005) report that most owners agree to this with only a few private owners reluctant to allow access due to privacy and security reasons. Describing the motivations of private and non-private land-owners for owning woodland, Church and Ravenscroft (2008) report that 73, 68, 48, 23 and 19\% of respondents mentioned wildlife habitat, landscape feature, reserve for nature, commercial timber and recreation respectively. According to Church and Ravenscroft (2008), these motivations reflect a broad view about the reasons for owning and managing woodlands even when they have very little commercial value.

Commercial timber production was identified as the most important ecosystem good for the agribusiness co-operative which probably reflects their business objectives. However, with the recent low price of timber and the availability of cheap imports it is recognised that timber sales alone do not provide adequate revenues for many owners. The low importance ( $0-5 \%$ of the total value) placed on the provision of fuelwood is also noteworthy in the target that by 2020 England should seek to harvest half of the currently unharvested biomass increment of woodlands as fuelwood (Forestry Commission, 2007). The importance placed on fuelwood was similar to the emphasis (2-3\% of the total value) placed on the potential of woodland to sequester carbon storage. Cannell et al. (1999) estimate that the accumulation of carbon in unharvested trees, forest litter, forest soils, and undecaying timber products from UK forests represent an annual sink of about $2.7 \mathrm{Mt}$ of carbon, or about $1.8 \%$ of annual current UK carbon emissions. Hence carbon sequestration can strengthen the case for multi-purpose woodland creation. 
The agribusiness co-operative also placed a 6\% weighting on the capacity of the woodland to provide employment; this was categorised as a provisioning use in the questionnaire. This was probably appropriate at Pegnut Wood where, once the trees were planted, thinning to maximise wood production on the largest trees had been the main on-site employment activity. However at the other sites, people were also employed to maintain rides, fences, gates and stiles, and these could relate to habitat and information functions. More fundamentally there is the question of whether "employment" should be categorised as an ecosystem "use" or an indicator of the "value", or level of human appreciation, that is placed on a use. The distinction between "use" and "value” is not always clear; for example De Groot et al. (2002) includes "small-scale subsistence farming" and "building and manufacturing" within a list of provisioning services for natural ecosystems. In addition there are some foresters who will gain enjoyment and utility from their employment in a woodland ecosystem in an analogous way to an individual who uses the ecosystem for recreation. Nevertheless it is probably more rigorous to restrict the "provisioning" ecosystem services to the production of woodland products (De Groot, 1992), and to use the term "employment" in the socio-economic valuation and analysis of a range of ecosystem services.

Two of the owners showed substantial concern that woodlands provide opportunities for fly tipping and the accumulation of litter and dog excrement. These "dis-services" could be associated with the woodland ecosystem restricting short-range visibility and creating "private" spaces: an ecosystem service which can be positive in other contexts. Whereas ecosystem services are generally discussed in terms of ecosystem payments to the owner, dis-services can result in prevention and remediation costs and the question of who should pay. Investment may be required in some form of security, education, or regular maintenance to address these and possible cumulative effects, i.e. the so called "dirt attracts dirt principle” (Irving, 1985).

\section{Government institutions}

The representative of the surveyed government institutions placed greatest value on the information function, specifically on uses such as walking, the provision of a beautiful landscape, and cultural benefit. The UK Department for the Environment, Food and Rural Affairs (DEFRA, 2006) argues that encounters with nature, such as with woodlands close to people's homes, have a positive impact on quality of life and health. The Forestry Commission seeks to promote greater involvement of people and communities in order to provide a more "socially inclusive resource" (O'Brien and Claridge, 2002). Such government institutions have considerable influence over land management practices in the UK, along with other institutions that create incentive structures which stimulate and enable landowners to allow public access. For example, in the UK the Countryside and Rights of Way Act (2000) made a range of provisions, which included access to open countryside, reforms to rights of way and nature conservation (Parker and Ravenscroft, 2001). Likewise the English Woodland Grant Scheme provides additional payments to landowners who provide and support public access to new woodlands.

\section{Conservation groups}

The conservation groups placed greatest value on the habitat (39\%) and information (30\%) functions of the community woodlands. Creating a habitat for wild plant and wild animal species (25\%) was their primary focus. Geist and Galatowitsch (1999) recognise 
the importance of conservation groups in proposing a model for successfully engaging such groups in ecological restoration for reversing losses in biodiversity. The conservation groups placed minimal value on the use of the woodlands for timber production (3\%). The mutual emphasis on the provision of habitat by voluntary conservation groups and other stakeholders, mean that such groups can usefully work together.

\section{Potential synergies and tensions}

Stakeholder ranking of the ecosystem functions and uses of community woods provides a method for identifying areas of mutual interest between stakeholder groups, and hence identify areas where they can work together. These are important considerations for implementing changes in institutional processes and arrangements put forward by Turner et al. (2003) to realise the benefit streams from multiple ecosystem use and non-use provision across a range of different stakeholders.

Each group of stakeholders placed a relatively high value on the information (30-50\%) and habitat (16-40\%) functions of community woodlands. These observed similarities in perceptions of the habitat and information ecosystem functions of community woodlands provide potential synergies. In 2006, the creation in England of a new organisation called Natural England brought together the habitat-focused work of English Nature together with the community-related activities of the Countryside Agency's Landscape, Access and Recreation Division. This new organisation could provide a good forum for identifying and harnessing similarities across different stakeholders.

Although each stakeholder group recognised the regulation function, it was not given the highest priority (10-18\%). This relatively low weighting creates a challenge for those like Hindmarch et al. (2006) who propose the need for a new social perspective and a range of policy reforms to address awareness of ecosystem services, which are essential to human life. The authors identify "blindness to ecosystem services" and the need for concepts, methods and supporting legislative instruments to internalise the value of ecosystem services in real world accounting processes. This would facilitate the importance of ecosystem services becoming "a matter of common social acceptance" (Hindmarch et al., 2006). This is particularly important for those services that are "invisible" and therefore not readily perceived by the senses (Lewan and Söderqvuist 2002) such as the regulation function. De Groot (1992) observed that although the regulation function may not provide direct economic benefits it maintains and conserves the environmental conditions necessary for most of the other ecosystem functions that provide direct benefits. All the stakeholders studied perceived the indirect contributions of the regulation function as minimal. Lewan and Söderqvuist (2002) underscore the need for the general public to gain a critical level of basic knowledge about the functions in nature, if these functions are to be valued in policy and economics. In other words, the public should gain some awareness to ensure public debate on issues associated with local partnerships in community woods.

One area of potential tension is in the different values placed on community woodland for the provision of timber. This ranged from $14 \%$ for the agri-business co-operative to $2 \%$ for local residents. This difference could generate tensions during typical tree felling 
activities. Hence a potential issue could be how to raise awareness of the potential benefits of some level of timber production in community woods.

A second area of potential tension was the perception of the negative services of community woodland. This was given a high priority by the agri-business owner (20\%), who would normally have to deal with the removal and control of goods and services which are thought to be negative, but a low value (6\%) by local residents who may not see it as their responsibility. Although negative services were not included in the initial ecosystem function framework, in this study it was instructive to include those ecosystem services which have a detrimental effect on human well-being. The need to address negative services can result in real financial costs for woodland owners. In such situations, it may be fruitful to facilitate discussions between owners and other stakeholders as to methods to resolve such issues. One possible approach is to integrate such an analysis of the synergies and tensions between stakeholders with the "Toolbox" described by Hislop et al. (2004) to provide opportunities to systematically develop dialogue and build partnerships between stakeholders.

\section{Conclusions}

The ecosystem function framework was applied in this paper to explore the stakeholder perceptions on the relative value of the different functions and services associated with community woodlands. By starting from a consideration of the capacity of natural processes and components in the woodland (e.g. the functions of the woodland) to provide goods and services, it provides a systematic structure for comparing the importance of a range of goods and services in a non-monetarised way. After an initial pilot study, it was also possible to modify the framework to consider positive and negative services. The application of the framework has highlighted the importance placed on the habitat and recreation services provided by woodland, as discussed by other authors, but it has also shown a significant, albeit low, appreciation of regulation services. Regulating services are sometimes overlooked and the framework could be one way of providing the new narrative, which O’Brien (2004) states is needed to describe public views of woodlands in the $21^{\text {st }}$ century.

Similar levels of importance placed on some services by different stakeholders provide opportunities for groups working together, i.e. conservation groups working with owners to enhance habitat services. By contrast, differences in levels of importance may suggest potential areas of tension. For example, a production-related activity such as thinning undertaken by the owner may be perceived as negative by local residents whose focus is habitat and recreation services. In such cases, the ecosystem functions could provide a useful heuristic framework for exploring and addressing the differences. It should also be noted that this research was limited to community woodlands where the owners had specifically planted their woodlands with the intention of providing public access. It is now recommended that non-community woodlands are studied to determine if the perceptions of the owners are similar. 


\section{Acknowledgements}

We wish to acknowledge the contributions of all the stakeholders who were contacted. Olivia Agbenyega was in receipt of a research studentship from the Government of Ghana whilst she undertook this research.

\section{References}

Arnberger, A., 2006. Recreation use of urban forests: an inter-area comparison. Urban Forestry \& Urban Greening, 4, 135-144.

Baltzer, K. 1998. Property Rights and the Use of Natural Resources. Institute of Economics, University of Copenhagen.

Bromley, D.W. 1991. Environment and Economy. Property Rights and Public Policy. Blackwell, Oxford.

Burgess, P.J., Graves, A.R., Goodall, G.A., Brierley, E.D.R., 2000. Bedfordshire Farm Woodland Demonstration Project. Final Report for European Commission Project ARINCO N ${ }^{0} 95$. Cranfield University, Bedfordshire, UK

Cannell, M.G.R., Milne, R., Hargreaves, K.J., Brown, T.A.W., Cruickshank, M.M., Bradley, R.I., Spencer, T., Hope, D., Billett, M.F., Adger, W.N., Subak, S. (1999). National inventories of terrestrial carbon sources and sinks: the U.K. experience. Climatic Change 42: 505-530.

Chambers, M.T.W., Price C., 1986. Recreational congestion: some hypotheses tested in the Forest of Dean. Journal of Rural Studies, 2 (1), 41-52.

Church, A., Ravenscroft N., 2008. Landowner Responses to Financial Incentive Schemes for Recreational Access to Woodlands in South East England. Land Use Policy, 25, 1-16.

Church, A., Ravenscroft N., Rogers G., 2005. Woodland Owners' Attitudes to Public Access Provision in South-East England. Information Note, Forestry Commission, Farnham, UK.

Costanza, R., d’Arge, R., de Groot, R., Farberk, S., Grasso, M., Hannon, B., Limburg, K., Naeem, S., O’Neill, R.V., Paruelo, J., Raskin, R.G., Sutton, P., van den Belt, M. 1997. The value of the world's ecosystem services and natural capital. Nature, 387, 253-260.

Daily, G., 1997. Nature's Services: Societal Dependence on Natural Ecosystems. Island Press, Washington DC.

DEFRA, 2006. England Trees, Woods and Forests: a Consultation Document. Department for the Environment, Food and Rural Affairs, London.

De Groot, R.S., 1992. Functions of Nature: Evaluation of Nature in Environmental Planning, Management and Decision Making. Wolters-Noordhoff, Netherlands.

De Groot, R.S., 2006. Function-analysis and valuation as a tool to assess land use conflicts in planning for sustainable multi-functional landscapes. Journal of Landscape and Urban Planning 75, 175-186.

De Groot, R.S., Wilson, M.A., Boumans, R.M.J., 2002. A typology for the classification, description and valuation of ecosystem functions, goods and services. Ecological Economics, 41 (3), 393-408.

Farber, S.C., Costanza, R., Wilson, M.A. 2002. Economic and ecological concepts for valuing ecosystem services. Ecological Economics 41, 375-392.

Forestry Commission, 1998. A Guide to the Woodland Grants Scheme December 1998. Forestry Commission, Edinburgh. 24 pp.

Forestry Commission, 2004. The UK Forestry Standard: The Government's Approach 
to Sustainable Forestry. Edinburgh: Forestry Commission.

Forestry Commission, 2007. A Woodfuel Strategy for England. Cambridge: Forestry Commission. 28 pp.

Friedman, A.L., Miles, S., 2006. Stakeholders: Theory and Practice. $1^{\text {st }}$ Edition. Oxford University Press, Oxford.

Geist C., Galatowitsch S. M., 1999. Reciprocal model for meeting ecological and human needs in restoration projects. Conservation Biology, 13 (5), 970-979.

Hein, L., van Koppen, K., de Groot, R.S., van Ierland, E. C. (2006). Spatial scales, stakeholders and the valuation of ecosystem services. Ecological Economics 57, 209-288.

Hindmarch, C., Harris, J., Morris, J., 2006. Growth and sustainability: integrating ecosystem services into economics. Biologist, 53 (3), 135-142.

Hislop, M., Twery, M. Vihemäk, H., 2004. Involving People in Forestry: A Toolbox for Public Involvement in Forest and Woodland Planning, Introduction. Forestry Commission, Edinburgh.

Hoehn, J.P., Lupi, F., Kaplowitz, M.D. 2003. Untying a Lancastrian bundle: valuing ecosystems and ecosystem services for wetland mitigation. Journal of Environmental Management, 68 (3), 263-272.

Irving, J. A., 1985. The Public in Your Woods: an Owner's Guide to Managing Urban Fringe Woodland for Recreation. Packard Publishing Limited, Chichester, UK

Lewan, L., Söderqvist, T., 2002. Knowledge and recognition of ecosystem services among the general public in a drainage basin in Scania, Southern Sweden . Ecological Economics, 42, 459-467.

Millennium Ecosystem Assessment, 2005. Ecosystems and Human Well-being: Synthesis. Island Press, Washington DC.

Neuman, W.L., 2003. Social Research Methods. 5th ed. Allyn and Bacon, USA.

O'Brien, E. A., Claridge J. A., Eds., 2002. Trees are Company: Social Science Research into Woodlands and the Natural Environment. Forestry Commission, Edinburgh.

O'Brien, E.A., 2004. A Sort of Magical Place: People's Experiences of Woodlands in Northwest and Southwest England. Forestry Commission, Farnham, UK.

Ode A., Fry G., 2006. A model for quantifying and predicting urban pressure on woodland. Landscape and Urban Planning, 77, 17-27.

Parker, G., Ravenscroft, N., 2001. Land, rights and the gift: the Countryside and Rights of Way Act 2000 and the negotiation of citizenship. Sociologia Ruralis, 41 (4), 381-398.

Ravnbord, H.M., Westermann, O., 2002. Understanding interdependencies: stakeholder identification and negotiation for collective natural resource management. Agricultural Systems 73, 41-56.

Rollinson, T.J.D., 1999. Farm woodlands - the role of the Forestry Commission. In: Burgess, P.J., Brierley, E.D.R., Morris, J., Evans, J. (Eds.). Farm Woodlands for the Future. Bios Scientific, Oxford, pp. 161-168.

Selman, P., 1996. The role of forestry in meeting planning objectives. Land Use Policy, 14 (1), 55-73.

Turner, R.K., van den Bergh, J.C.J.M., Söderqvist, T., Barendregt, A., van der Straaten, J., Maltby, E., van Ierland, E.C., 2000. Ecological-economic analysis of wetlands: scientific integration for management and policy. Ecological Economics 35 (1), 7-23.

Turner, R.K., Paavola, J., Cooper, P., Farber, S., Jessamy, V., Georgiou, S., 2003. 
Valuing nature: lessons learned and future research direction. Ecological Economics, 46, 493-510.

Wilson, M.A., Howarth, R.B. 2002. Discourse-based valuation of ecosystem services: establishing fair outcomes through group deliberation. Ecological Economics, 41 (3), 431-443.

Zhang, W., Ricketts, T.H., Kremen, C., Carney, K., Swinton, S.M., 2007. Ecosystem services and dis-services to agriculture. Ecological Economics 64(2), 253-260. 